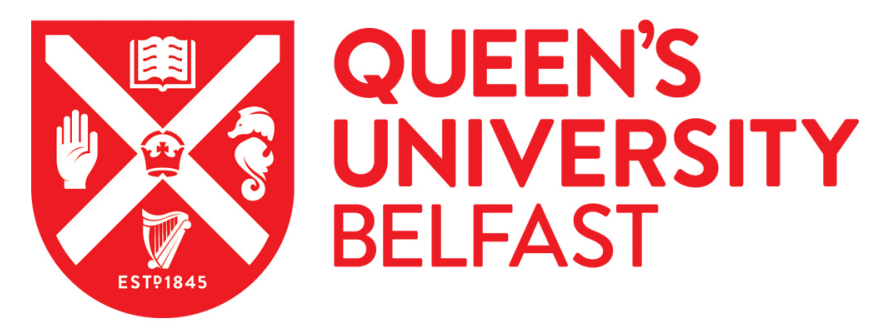

\title{
Empirical testing of genuine savings as an indicator of weak sustainability: a three-country analysis of long run trends
}

Hanley, N., Oxley, L., Greasley, D., McLaughlin, E., \& Blum, M. (2016). Empirical testing of genuine savings as an indicator of weak sustainability: a three-country analysis of long run trends. Environmental and Resource Economics, 63(2), 313-338. https://doi.org/10.1007/s10640-015-9928-7

Published in:

Environmental and Resource Economics

Document Version:

Peer reviewed version

Queen's University Belfast - Research Portal:

Link to publication record in Queen's University Belfast Research Portal

Publisher rights

(c) 2016 Springer International Publishing.

The final publication is available at Springer via http://dx.doi.org/10.1007/s10640-015-9928-7

\section{General rights}

Copyright for the publications made accessible via the Queen's University Belfast Research Portal is retained by the author(s) and / or other copyright owners and it is a condition of accessing these publications that users recognise and abide by the legal requirements associated with these rights.

Take down policy

The Research Portal is Queen's institutional repository that provides access to Queen's research output. Every effort has been made to ensure that content in the Research Portal does not infringe any person's rights, or applicable UK laws. If you discover content in the Research Portal that you believe breaches copyright or violates any law, please contact openaccess@qub.ac.uk. 


\title{
Empirical testing of Genuine Savings as an indicator of weak sustainability: a three-country analysis of long-run trends.
}

Nick Hanley* (University of St.Andrews), Les Oxley (University of Waikato), David Greasley (University of Edinburgh), Eoin McLaughlin (University of St. Andrews) and Matthias Blum (Queens University, Belfast).

Submitted to special issue of Environmental and Resource Economics in honour of Anil Markandya.

\begin{abstract}
:
Genuine Savings has emerged as a widely-used indicator of sustainable development. This approach to conceptualising sustainability has strong links to work published by Anil Markandya and colleagues over 20 years ago. In this paper, we use long-term data stretching back to 1870 to undertake empirical tests of the relationship between Genuine Savings (GS) and future consumption for three countries: Britain, the USA and Germany. Our tests are based on an underlying theoretical relationship between GS and changes in the present value of future consumption. Based on both single country and panel results, we find evidence supporting the existence of a cointegrating (long-run equilibrium) relationship between GS and future consumption, and fail to reject the underlying basic theoretical result on the relationship between these two macroeconomic variables. These findings provide some support for the GS measure of weak sustainability.
\end{abstract}

Keywords:

Weak sustainability; Genuine Savings; comprehensive investment; economic history; sustainable development indicators; cointegration.

accepted version, May 2015. 


\section{Introduction}

Anil Markandya's name is associated with some of the most important work on the economics of sustainable development. Along with David Pearce and Edward Barbier, Markandya developed the idea of weak sustainability, and the notion that changes in a nation's total capital stock (referred to today as comprehensive or inclusive wealth) can indicate whether a country's development is sustainable (Pearce et al, 1989; Markanya et al, 1990; Barbier et al, 2013). This led to the proposing of a specific test for weak sustainability by Pearce and Atkinson (1993) known as "Genuine Savings." Whilst there are many competing indicators of sustainable development that are grounded in ideas of strong sustainability (Bohringer and Jochem, 2007; Dietz and Neumayer, 2007), and other indicators of weak sustainability (such as Green Net National Product or Green Net National Income: Pezzey, 2004; Pezzey et al, 2006; Chichilnisky et al, 1995; Mota et al, 2010), Genuine Savings appears to be the leading candidate for a macroeconomic sustainability indicator to emerge from economics (e.g. Arrow et al, 2012), and has been adopted by the World Bank as a preferred measure (World Bank, 2006, 2011). However, one should also note the existence of papers which cast doubt on the information quality associated with GS-type indicators (e.g. Tanguy, 2010).

In this paper, we construct long-run data sets for changes in a country's total capital - the sum of its produced, natural and human capital, plus an adjustment for changes in Total Factor Productivity which attempts to measure the effects of technological progress on production possibilities. The data are then used to test whether year-on-year changes in a country's stock of total capital predict changes in its future consumption in a manner consistent with the theory underlying the Genuine Savings (GS) indicator. The main objective of the paper, then, is to test

\footnotetext{
${ }^{1}$ Also referred to as Adjusted Net Savings or Comprehensive Investment.
} 
the theoretical relationship between GS and future consumption using long-run data for three OECD countries. By "long-run" here, we mean a period of almost 140 years. Most previous tests of GS have focussed on rather shorter time periods (Ferreira and Vincent 2005, Ferreira, Hamilton and Vincent, 2008, Mota and Domingos, 2013), which can be argued to be less suitable for an examination of the long-run properties of an indicator. Greasley et al (2014) argue that GS measures should include an estimate of the value of technological progress, and they report results in favour of an augmented GS model using long-run British data from 1750. However, OECD countries are not homogeneous, and a wider assessment of the GS model is desirable. Thus, this paper investigates the relationship between GS and future consumption for 3 countries (Britain, the USA and Germany).

The economies in our panel have disparate development experiences. Britain was the industrializing pioneer and its experience as the first industrial nation is (by definition) atypical. The followers, the USA and Germany had different paths to industrial and economic development. The continental economy of the USA developed utilizing an abundance of land and mineral resources, which concomitantly influenced its technology (Allen 2014). In contrast, the industrial economy of Germany emerged from within continental Europe and, in contrast to Britain, experienced dramatic institutional change since 1870 (Olson 1982). The distinctive history of the three countries offers a series of natural experiments which provide a strong challenge for the GS model. Their institutions and the resource endowments differed markedly, and each has been affected in different ways by shocks, including the world wars and the great depression. If measures of GS are shown to consistently predict changes in future consumption in all three of these countries, that finding would greatly reinforce the credibility of the indicator. 
In this paper, empirical tests are undertaken using the framework suggested by Ferreira, Hamilton and Vincent (2008). We also test whether or not GS and the Present Value (PV) of future changes in consumption are cointegrated. A finding of cointegration is taken to be evidence of a long-run equilibrium relationship which supports the theoretical findings of authors such as Hamilton and Hartwick (2005). The main contribution of the paper thus lies in finding empirical evidence in support of GS as a long-run forward-looking indicator of sustainable development for disparate OECD countries. Thus, whilst Greasley et al (2014) offer findings on the existence of a cointegrating relationship between GS and future consumption for just one country, in this paper we offer evidence on the existence of such a relationship across a panel of three very different economies. This cross-country comparison strengthens the evidence base considerably.

\section{The evolution of genuine savings as an indicator of weak sustainability.}

One of the first publications to explore the concept of weak sustainability was Pearce et al (1989) in Blueprint for a Green Economy. The authors define sustainable development as a situation where well-being for a given population is not declining, or preferably increasing, over time. Based on Solow (1986), they state that this requires that each generation pass on an undiminished stock of total capital to the next generation, meeting a requirement for intergenerational fairness and non-declining consumption over time. They note arguments over the extent to which a decline in natural capital, e.g. a loss of forests, can be compensated for by an increase in produced or human capital, leading to two cases for this intergenerational rule:

1. Sustainable development requires non-declining total wealth

2. Sustainable development requires non-declining natural wealth. 
We now view the first as representing the idea of weak sustainability, and the second as representing the idea of strong sustainability. ${ }^{2}$ Interestingly, whilst most focus today is on the degree of substitutability between produced, human and natural capital in deciding which of the above is consistent with non-declining well-being over time, Pearce et al (1989) provide four reasons why we might need to impose rule (2) rather than rule (1) for welfare to be non-declining. These are (i) lack of sufficient substitutability (ii) irreversibility (iii) uncertainty and (iv) intragenerational equity, on the grounds that the poor are often more adversely affected by reductions in environmental quality than the rich. There are indications in the text that Pearce et al thought that constraint (2) should always be taken account of in some way, as sustainability could not be assured regardless of the state of a country's natural capital. For example, on page 48 they note: ..."there are strong reasons to think of sustainable development as involving....that the stock of environmental assets as a whole should not decrease"'(see also Helm, 2015). This is more consistent with the idea of strong sustainability than weak sustainability. Later on, they propose implementing this at the level of programmes of investment by requiring shadow projects which offset the value of environmental losses.

The idea that sustainable development requires non-declining natural capital is stated more clearly in Pearce et al (1990). They define natural capital as “...the stock of all environmental and natural resource assets...from oil in the ground to the quality of soil and groundwater, from the stock of fish in the oceans to the capacity of the globe to recycle and absorb carbon" (page 1). How this natural capital stock can be maintained as non-declining is put in terms of the net value of environmental damages. When evaluated at the programme level, this net environmental damage

\footnotetext{
${ }^{2}$ Note that Pearce et al (1989) use these terms rather differently: they define weak sustainability as a situation where, across a portfolio of projects and over time, the net environmental cost of implementing the portfolio is zero or negative. For strong sustainability, they require this non-positive condition to hold for every time period: see Chapter 5. It is interesting that by the time the "new blueprint" was published Barbier and Markandya (2013), the difference between weak and strong sustainability revolves around the substitutability of different forms of capital for each other. Thus, weak sustainability takes rule (1) as being the relevant rule; strong sustainability takes rule (2).
} 
value should be zero or negative, either when discounted across time or at each point in time. This outcome, they wrote, could be achieved by commissioning shadow projects which have the purpose of off-setting environmental damages from other projects in the programme. Such shadow projects might well yield negative NPVs when appraised in isolation, implying that there is a sustainability "price" being paid by the economy, which is the marginal cost of imposing a constraint of no positive environmental damage.

The work of Pearce and Atkinson (1993) in developing the idea of Genuine Savings (GS) as an indicator of sustainability moves away from the notion that sustainability by definition requires zero net loss of natural capital (zero environmental damage, in the language of the previous paragraph), since GS allows for reductions in natural capital to be offset by increases in human, social or produced capital. Neumayer (2010) describes GS as a weak sustainability indicator as it presumes that natural capital can be substituted for by other forms of capital ${ }^{3}$ (so long as changes in each are correctly priced), and that non-declining consumption over time is possible so long as the total capital stock is non-declining. GS adds up the value of year-on-year changes in each individual element of the capital stock of a country, valuing these changes using shadow prices which reflect the marginal value product of each stock in terms of its contribution to social welfare, which in turn is defined as the present value of aggregated utility over infinite time.

Changes in the stock of certain pollutants (such as $\mathrm{CO}_{2}$ ) can be subtracted from the index, valued using marginal damage costs. Changes in human capital can be approximated using expenditures on education, as a rate of return on time spent in education, or as a measure of discounted lifetime earnings by skill level. The effects of technological change, resource price appreciation (capital gains/losses) for resource exporters and importers, and population change can also be incorporated

\footnotetext{
${ }^{3}$ Pearce and Atkinson state: "To do this we adopt a neoclassical stance and assume the possibility of substitution between 'natural' and 'man-made' capital' (page 104).
} 
into the GS indicator (Pezzey et al, 2006; Ferreira et al, 2008). The intuition of Pearce and Atkinson (1993) was that countries with positive levels of GS would satisfy a requirement of weak sustainability, since by implication their aggregate capital stocks would not be declining in value. Concomitantly, countries with negative GS values would be experiencing unsustainable development. As they stated: “...even on (such) a weak sustainability rule, many countries are unlikely to pass a (stronger) sustainability test” (page 105).

The theoretical link between genuine savings and future consumption has since been investigated by a number of authors, including Hamilton and Clemens (1999), Hamilton and Hartwick (2005) and Hamilton and Withagen (2007): see Neumayer (2010) for an excellent overview. Pezzey (2004) argues that GS is a one-sided indicator which can only indicate un-sustainability, due to the failure to use what have been termed "sustainability prices" which include sustainability constraints to value changes in capital stocks. A positive value of GS could give a misleading signal of weak sustainability if natural resources are under-priced or being harvested unsustainably (Neumayer, 2010). Moreover, Pezzey argues that there is no theory linking negative GS with un-sustainability away from an optimal growth path. An alternative perspective offered by Dasgupta and Maler (2004) shows that a measure of year-on-year change in wealth stocks (GS, in our terminology) can be used as an indicator of sustainable increases in well-being in nonoptimising economies. Arrow et al (2012) define comprehensive investment as the change in comprehensive wealth at time $t$, and claim that intergenerational well-being is rising over future periods if comprehensive investment - GS, in our terminology - is positive when evaluated at the correct shadow prices in the current period.

Starting from the model of Hamilton and Hartwick (2005), Ferreira, Hamilton and Vincent (2008) showed, with a constant population growth rate of $\gamma$, a population at time $t$ of $N$, a consumption 
discount rate of $\rho$, and year-on-year change in produced capital $K$ denoted $\dot{K}$, that per capita genuine savings $g$ is given by:

$g=\frac{\dot{K}}{N}-F_{R} r-\gamma \omega$

where $\left(F_{R} r\right)$ is the shadow value of per capita natural capital extraction (e.g. fossil fuel extraction) and $\omega$ is per capita wealth, which is the sum of per capita natural and produced capital stocks $W$ at time $t$ divided by the population $N$. This shows GS is determined by per capita net change in produced and natural capital (the first two terms on the right-hand side of equation 1) adjusted by a "wealth dilution effect" from population growth $-\gamma \omega$. The key theoretical relationship is that in any period $t$, the value of $g$ is equal to the discounted value of changes in per capita consumption from $t$ to infinity if the consumption discount rate $\rho$ is adjusted downwards by the (constant) population growth rate. If population grows at a varying rate, then the relationship between per capita GS and the present value of changes in future consumption is altered. Ferreira et al express this relationship in discrete time as follows:

$\sum_{v=t+1}^{t+T} \frac{\left(\frac{C_{i v+1}}{N_{i v+1}}-C_{i v} / N_{i v}\right)+\left(\gamma_{i v+1}-\gamma_{i v}\right)\left(W_{i v} / N_{i v}\right)}{\prod_{j=t+1}^{v}\left(1+\rho_{i j}-\gamma_{i j}\right)}=g_{i t}$

where for country $i$, all of the terms are as described above. $W$ can be extended to include other forms of capital, such as human or social capital. Consumption here refers to the full vector of goods and services (market and non-market) which determine utility. Equation (2) states that, in a competitive economy, the per capita rate of genuine saving for country $i$ at time $t$ should be equal to the present value of future changes in per capita consumption adjusted for a term which shows the effects of population growth on per capita wealth - the wealth dilution effect with nonconstant population growth rates. There is thus a theoretical claim about the signal which a positive or negative value of GS sends, which seems worthy of empirical investigation. 


\section{Empirical tests of Genuine Savings}

Empirical work to date includes World Bank $(2006,2011)$ which reports GS calculations for most countries. A number of papers test the relationship between GS and future consumption. Note that all of these tests relate to the relationship between GS and future consumption, rather than future well-being. This is due to the problems in obtaining consistent and comprehensive measures of contributions to well-being other than consumption (such as the shadow value of all environmental amenities in any year). Ferreira and Vincent (2005) base their econometric testing on a representation of an underlying theoretical relationship between GS and future consumption:

$$
\Delta_{\mathrm{it}}=\beta_{0}+\beta_{1} S_{\mathrm{it}}+\varepsilon_{\mathrm{it}}
$$

where $\Delta_{\mathrm{it}}$ is given by $\left((\bar{c})-c_{t}\right)$, with the former term representing average (per capita) consumption over some time period, and the latter consumption in the current period; where $S$ is a measure of net investment (net change in total capital), and $\varepsilon$ is an error term. $\Delta_{\text {it }}$ thus represents the difference between current period consumption at time $t$ and average future consumption in country $i$. A test for the validity of this relationship as a predictor of future consumption is then whether or not $\beta_{0}=0$ and $\beta_{1}=1$. Using World Bank data for 136 countries over the period 19702000, Ferreira and Vincent initially calculate $\Delta_{\mathrm{it}}$ over 10 years, so that their estimation period is 1970-1991. The authors propose 4 alternative measures of $S$; gross investment in produced capital; net investment in produced capital; net investment adjusted for depletion of natural capital (green net savings), and finally green net savings augmented by investment in education, which they term Genuine Savings. These 4 measures represent an increasingly comprehensive view of what is counted as part of a country's capital stock. Based upon this approach, they then test four hypotheses:

$\mathrm{H} 1: \beta_{0}=0 ;$ and $\beta_{1}=1$ (jointly).

H2: $\beta_{1}>0$ and $\rightarrow 1$ as $S$ includes more types of capital. 
$\mathrm{H} 3: \beta_{1}>0$.

H4: The predictive power of S improves as more types of capital are added.

To test H1-H3, the authors estimate a series of 2SLS panel models with and without country fixed effects using the different definitions of $S$ as noted above. Their results suggest that $\mathrm{H} 1$ is rejected for all definitions of $S$. For $\mathrm{H} 2$, they find that $\beta_{1}$ is sometimes positive (although negative for OECD countries), and that its absolute value increases as more comprehensive measures of the capital stock are used, although it falls when education spending is included. The authors speculate that this reflects the extent to which current education spending is a poor measure of changes in the stock of human capital. H3 is not rejected. H4 is evaluated by generating a set of one-step-ahead forecasts of $\Delta_{\mathrm{it}}$, with forecasts compared using the Theil inequality statistic for each country. The results show that the predictive accuracy of $S$ improves as one adds more types of capital to its calculation. However a pure ARIMA time series model outperforms even the most comprehensive definition of $S$.

A similar test of the predictive power of GS in terms of future consumption, using the same data set, is reported in World Bank (2006). Based on Hamilton and Hartwick (2005), the authors show that the change in the Present Value of future changes in consumption (PVC) in a competitive economy $i$ where externalities are internalised should be determined by:

$$
\mathrm{PVC}_{\mathrm{i}}=\beta_{0}+\beta_{1} \mathrm{G}_{\mathrm{i}}+\varepsilon_{\mathrm{i}}
$$

where $G_{i}$ is a measure of net investment in country $i$ (corresponding to $S_{i}$ in equation 3). Using simple OLS regressions for each year from 1976-1980 across the countries in the sample and a measurement period for PVC of 1976-2000, they fail to reject the hypothesis that $\beta_{1}=1$ for the Genuine Savings measure of G, where net investment included depletion of natural resources. They also find, however, that this gave a number of false positive and false negative signals about the future path of consumption. 
Ferreira, Hamilton and Vincent (2008) allow for population growth in their test of the relationship between the present value of changes in future consumption and genuine savings. They employ a World Bank data set of 64 developing countries over the period 1970-2003. This study uses increasingly-comprehensive measures of changes in a country's assets: gross savings, net savings (i.e. net investment in produced capital), green savings (net savings minus depreciation of elements of natural capital) and population-adjusted savings (green savings adjusted by a "wealth dilution" term). They test the joint hypothesis that $\beta_{0}=0$ and $\beta_{1}=1$; and a weaker hypothesis that $\beta_{1}>0$. They find that the hypothesis $\beta_{1}>0$ is supported only for green savings and its populationadjusted equivalent. However, the estimates of $\beta_{1}$ remain "significantly below 1 " in all four models. Mota and Domingos (2013) use data for Portugal from 1991 to test the underlying theoretical relationship between both GS and what they refer to as Green Net National Income, with changes in future consumption. Whilst rejecting the precise predictions of theory, they conclude that both indicators "move in the same direction as changes in welfare" (page 195).

Finally, the most recent test of GS as a predictor of future consumption is Greasley et al (2014) and McLaughlin et al (2014), who use British data from 1750 to $2000^{4}$. The value of GS is positive for almost all of this time period, with the exception of the first and second World Wars; although allowing for a wealth dilution effect produces more time periods when GS is negative. Greasley et al (2014) find that the choice of discount rate and time horizon over which changes in consumption are considered all have sizeable effects on the estimated parameters for $\beta_{1}$, not just the alternative measures of changes in capital. Similar findings emerge when real wages rather than consumption is used as an indicator of future well-being. They also find that the inclusion of measures of technological change, which they proxy using the present value of Total Factor

\footnotetext{
${ }^{4}$ Note that our British data goes back to 1760 , but for the present paper we restrict our attention to the period from 1870 onwards, since that allows a comparison on a like-for-like basis between the three countries.
} 
Productivity change, gives $\beta_{1}$ coefficients close to 1 in most cases. Once technological progress is included within the measure of GS, then a cointegrating relationship is detected between GS and consumption growth, implying that GS predicts future changes in consumption.

In the present paper, we use data from Germany, the USA and Britain to construct tests of the hypothesised relationship between alternative measures of GS and future consumption over the period 1870 to 2008. Specifically, based on the framework of Ferreira, Hamilton and Vincent (2008) explained in Section 2, we test if, given the underlying theoretical relationship for country $i$ :

$$
P V C_{i}=\beta_{0}+\beta_{1} G S_{\mathrm{i}}+\varepsilon_{\mathrm{i}}
$$

where $P V C_{i}$ is the present value of future changes in consumption over some defined period, and GS is a measure of Genuine Savings, whether the following hypotheses hold ${ }^{5}$ :

$$
\begin{aligned}
& \mathrm{H}^{*} 1: \beta_{0}=0 ; \\
& \mathrm{H}^{*} 2: \beta_{1}=1 ; \\
& \mathrm{H}^{*} 3: \beta_{0}=0 ; \text { and } \beta_{1}=1 \text { jointly. }
\end{aligned}
$$

We also test whether the time series for $P V C$ and $G S$ are cointegrated for each country, since this reveals whether a long-run equilibrium relationship exists between the two data series. If $P V C$ and $G S$ are cointegrated, then this implies that the value of $G S$ in any period predicts the values of $P V C$ in future periods.

\section{Data}

The data sources used in this paper are outlined in Greasley et al (2013 \& 2014) and Blum et al (2013), and are also summarised in the data appendix to this paper. The time period over which the data stretch is $1870-2008$. The data for each country is converted into 1990 international

\footnotetext{
${ }^{5}$ We do not include a wealth dilution term in the calculations of per capita GS in this paper.
} 
Geary-Khamis dollars following methodology outlined by Maddison (2001, table A1). This is a common transformation used in comparative economic analysis. For each country we have constructed measures of Genuine Savings using long-run data on net fixed capital formation, net overseas investment, natural resource extraction and public education expenditure. Information on changes in produced capital (net fixed), overseas investments, inventories and consumption come from sources such as Feinstein and Pollard (1988), Rhode (2002) and Hoffman et al (1965). Depletion of oil, gas, coal, iron ore and a range of other minerals is included in the calculation of changes in natural capital, along with changes in the value of forest stocks ${ }^{6}$. These changes in elements of the natural capital stock are valued using estimated rents (price minus marginal cost). Costs mainly reflect labour costs, whilst prices are estimates of world prices for most nonrenewables. For non-renewables such as coal and iron ore, the annual change in the physical stock between any two years is approximated using production data or estimates of production for each year. For forests, we use estimates of area under forest and standing timber volumes in each year to calculate the change in the stock year-on-year. For changes in human capital, we use data on public sector spending on education, collected from a number of sources such as Carter et al (2006). We do not include CO2 emissions in the calculation of GS: for a treatment of the inclusion of CO2 in this framework see Kunnas et al (2014) and Blum et al (2013).

\section{Figure 1 here}

The GS data used in the paper are shown in figure 1, and are presented in per capita terms. As will be recalled from section 2, a negative value for GS signals unsustainability. Britain has a negative

\footnotetext{
${ }^{6} \mathrm{We}$ are not convinced that the theory makes clear what one does about new discoveries in GS accounting. Clearly, finding an oil deposit increases the known stock of reserves, although it only increases the known economic reserve if the price/cost ratio is bigger than one. However, it does not increase the finite stock in the ground. Depletion, however, clearly reduces both the known stock and the un-known stock. For all of the non-renewable resources included in the database for Germany, the USA and Britain, we use production (ie extraction) in year $t$ as the measure of depletion in that year. Finding new resources in year $t$ might affect production, and thus measured depletion in years $t+1, t+2 \ldots$, but we do not include this in the depletion term for year $t$.
} 
GS during the two world wars, but it is otherwise positive. For the USA, GS is negative during the Great Depression, and at the end of WW2, but is otherwise positive. For Germany, there is a large crash in GS during and just after WW2, but then a sharp recovery. All countries show no signal of unsustainable development in the last 50 years. Net produced investment forms a large part of GS in all three countries, but education investment increases in importance after 1945. For Britain 1860-1914 GS and net produced investment respectively average $7.68 \%$ and $9.17 \%$ of GDP, with the difference largely reflecting natural resource depletion. In contrast British GS exceeds net produced investment $1946-2000$ as education investment more than offsets the depletion of minerals. The rise in education investment in the USA was especially strong after 1945 . Whereas net produced investment and GS have similar values in the USA before WW2, public investment in education averages over $6 \%$ of GDP since the 1960s, to offset natural capital depletion and become the largest component of GS. Rather differently, in Germany the high ratio of GS and GDP by the 1960s rested chiefly on higher net produced investment (Blum et al, 2013). Since the 1970s natural capital depletion and net produced investment diminished relative to GDP in Germany, but higher education investment maintained the GS/GDP ratio at around $10 \%$. Table 1 shows this decomposition.

Weitzman (1997) suggested that a technological change premium could be as high as 40 per cent of Net National Product, and that omitting a technological progress measure would mis-state the degree of sustainability of an economy. Pemberton and Ulph (2001), Pezzey (2004) and Pezzey et al (2006) have also commented on the need to include (exogenous) changes in technology in measures of a nation's capital stocks and GS. To augment the measure of GS, we utilize estimates of trend Total Factor Productivity (TFP) growth to reflect how exogenous technological progress changes the total stock of capital, as argued by Pezzey (2004). Pezzey et al (2006, Equations 14 and 15) show how the present value of the TFP, limited to a 20 year period in accounting period, 
may be used to proxy the "value of time" or the value of exogenous technological progress. ${ }^{7} \mathrm{We}$ construct country specific trend TFP rates and calculate the net present value of TFP growth over 20 year horizons. TFP is a growth accounting residual; it is the total output not caused by measured inputs (labour-hours and produced capital here) in an underlying production function. Omitted forms of capital, including social and institutional factors, are thus captured in the Solow residual along with exogenous technological change. ${ }^{8}$ Strictly, therefore, our measure of exogenous technological progress may include changes in other, unmeasured forms of capital which make up comprehensive wealth. Nevertheless, the value of exogenous technological progress as proxied by TFP growth is added to our GS measure, and denoted GSTFP. We find that the present value of TFP averages $26 \%, 19 \%$, and $34 \%$ percent of GDP in the USA, Britain and Germany respectively over the period 1870-1990. GSTFP values are illustrated in Figure 2. They show a more positive signal of sustainability for all three countries: Britain and USA now have no periods where the technological progress-augmented GS is negative.

\section{Figure 2 here}

Our measure of future consumption is derived from data on consumption per capita. From the underlying data in Figure 3, the net present value of future changes in consumption are calculated using country specific discount rates (Figure 4). These annual rates of 3.5 per cent for the USA, 2.5 per cent for Britain and 1.95 per cent for Germany are average real interest rates. Three time horizons of 20,30, and 50 years are used to calculate the PV of changes in future consumption measure. ${ }^{9}$ For example the 20 years horizon measure in 1987 is the present value of

\footnotetext{
${ }^{7}$ Pezzey et al (2006) also include the value of natural resource capital gains in their measure of the value of time. However, this element is excluded in our measure in the absence of convincing evidence that relative prices favour natural capital in the long-run (Greasley et al, 2014).

${ }^{8}$ The output measure in the TFP is conventional GDP and not alternative "Green" adjusted variants nor does our TFP calculation incorporate "green" capital (e.g. see Mota et al (2010) for discussion).

${ }^{9}$ Note that we have adopted a slightly different convention to calculating the consumption variable here compared to Greasley et al (2014). In the present paper, we add up the discounted values of differences between pairs of years (t)
} 
changes in consumption per capita from 1988 to 2008, and so forth for the respective time horizons.

\section{Figure 3 here}

\section{Figure 4 here}

\section{Econometric Approach}

We are primarily interested in testing the hypotheses:

$$
\begin{aligned}
& \mathrm{H}^{*} 1: \beta_{0}=0 ; \\
& \mathrm{H}^{*} 2: \beta_{1}=1 ; \\
& \mathrm{H}^{*} 3: \beta_{0}=0 ; \text { and } \beta_{1}=1 \text { jointly. }
\end{aligned}
$$

The econometric approach used here was chosen to deal with potential non-stationarity in the time series data described in the previous section. Without appropriate methods, parameter estimates may be inefficient or spurious and the usual significance tests may be invalid. Engle and Granger (1987) show that a linear combination of two or more series that are integrated of order 1 may be stationary. The linear combination, if it exists, defines a cointegrating relationship where the resulting vector characterises the long-run relationship between the variables. However, cointegrating relationships do not exist with all combinations of non- stationary series.

There are a range of methods available to test for the existence of cointegration ranging from the simple and popular Engle-Granger (1987) 'two-step' OLS approach to the maximum likelihoodbased tests of Johansen (1997) and the Phillips and Hansen's (1990) Fully Modified OLS (FMOLS). Tests that use the residuals derived from the two step process of Engle-Granger have the property of a generated regressor (Oxley and McAleer, 1993; Greasley and Oxley, 2010). The 
critical values of the ADF test when used in the results' tables below adjust for this property. The results presented as Tables 2-6 report Engle-Granger ${ }^{10}$ OLS-based results. In addition to the individual country-level tests of the three hypotheses set out above, we also consider panel based estimation by combining the three country samples into a balanced panel (Tables 7-8). This allows us to consider tests of the three hypotheses with this combined data, along with additional restrictions such as fixed effect estimation and the existence of panel cointegration. This was done utilising the test proposed by Kao (1999), which explicitly specifies cross-section specific intercepts (Table 9).

It should be stressed however, that a finding of non-cointegration does not necessarily invalidate the hypothesis testing results, implying instead that they are less robust. As will be seen in what is presented below, coefficient estimates in (statistically) non-cointegrated models, and the inferences made, are generally very similar to cases where cointegration has been established. At this point we also reiterate that in the results presented below are specifically and solely concerned with consideration of the results as tests of the size, significance and signs of the parameters $\beta_{0}$ and $\beta_{1}$; these results are not structural models of the growth process. However, finding evidence of cointegration does indicate a long-run equilibrium relationship between Genuine Savings and the present value of changes in future consumption, and of a predictive power for GS in terms of future consumption flows.

\section{Results}

Our main empirical finding is that higher values of Genuine Savings in each of the three countries is associated with higher levels of future consumption. In the British case, for GS, the estimates of

\footnotetext{
${ }^{10}$ Given that estimation is effectively bi-variate the potential issue of potential multiple cointegrating vectors is ruledout.
} 
$\beta_{1}$ in the upper panel of Table 2 are positive and, ostensibly, statistically significant over 20 and 30 year horizons. For these 2 time horizons then, an increase in a country's comprehensive wealth in period $t_{o}$ is associated with higher levels of future consumption in both $\left[t_{1} \ldots t_{20}\right]$ and $\left[t_{1} \ldots t_{30}\right]$. Perversely, over the 50 year horizon, the estimate of $\beta_{1}$ is lower and loses statistical significance. The statistical significance of the estimated parameters for GS needs to be treated with caution however, given evidence of an absence of cointegration, since the ADF statistics in column 8 do not reject the hypothesis of non cointegration at conventional levels of significance.

The technology-augmented results for GSTFP are presented in the lower panel of Table 2, and these provide more robust results given that they reject the null of non-cointegration, and yield estimates of $\beta_{1}$ over $30-50$ years horizons that cluster around $0.78-1.18$. However, the hypothesis $\beta_{1}=1$ is rejected, as is the stronger joint hypothesis $\beta_{0}=0 ; \beta_{1}=1$. These results conform to those of Greasley et al (2014, Table 5) where GSTFP20 incorporates estimates of the technology premium looking forward over 20 years. In contrast, the Greasley et al (2014) results for GSTFP30, which measures the technology premium over 30 years, do not reject the $\beta_{1}=1$ sustainability hypothesis for changes in future consumption over 50 years. Collectively, the British results provide support for using the broader genuine savings measure GSTFP as an indicator of weak sustainability over future consumption horizons up to 50 years ahead. They highlight the importance of including the value of changes technology in the measure of genuine savings. Given the evidence of cointegration, there would thus seem to have been a long-run equilibrium relationship between a technological change-enhanced measure of Genuine Savings and the future path of consumption in Britain over this 140 year period.

Turning to the USA results presented in the upper panel of Table 3, over the 20 and 30 years consumption horizons, the estimates of $\beta_{1}$ suggest a near one to one relationship between GS and 
the present value of changes in future consumption. Thus, adding to the USA's total capital stocks increased the value of future consumption. In neither case is the hypothesis $\beta_{1}=1$ rejected, but the robustness of these results needs to be judged in the context of the non-cointegration finding. In contrast, over the 50 years horizon, a negative, but statistically insignificant estimate of $\beta_{1}$ is observed. The likely reason for the perverse USA GS results over the 50 years horizon is worth spelling out. USA GS per capita shows a long period of decline from a peak around 1907 to low points during the Great Depression and World War Two (Figure 1). The long GS per capita decline principally reflected low rates of produced investment, which were exacerbated by natural resource depletion. Indeed, it was not until the mid-1960s that USA real GS per capita exceeded the peak of 1907. In contrast, over a 50 years horizon, the changes in the present value of future consumption show a steady upward trajectory (Figure 4). Over shorter horizons the annual shifts in GS and the value of future changes in consumption are more closely aligned, but the symmetry sometimes disappears over the longer horizon. To reiterate, for the GS measure, the negative estimate of $\beta_{1}=-0.06$ over the 50 years horizon arises from a correspondence between diminished investment and higher future changes in consumption which persisted in the USA for much of the twentieth century.

The reason why the upward movement in the future changes of consumption continued, despite the long period of GS per capita decline, is readily explained by technological progress. In the lower panel of Table 3, GS augmented with exogenous technology, GSTFP, yields estimates which are more favourable to the sustainability hypotheses, especially over the 50 years horizon. Both the weaker hypothesis $\beta_{1}=1$ and the strong joint form, $\beta_{0}=0 ; \beta_{1}=1$, are not rejected looking 50 years ahead. However, an important caveat is that the null of non-cointegration is not rejected for any variant of the results in Table 3. 
To consider the apparent issue of non-cointegration further we investigate two variants of the approach used to produce the results presented as Table 3. Firstly, it is well known that ADF 'unit root' tests are fragile in the presence of breaks in levels, including those associated with wars or the Great Depression (Perron 1989, Greasley and Oxley 1996), and accordingly the results in Table 4 include a dummy variable to allow for a levels shift around the Great Depression. This dummy effectively captures the idiosyncratic vagaries in the series discussed above. In all the cases of the GSTFP results, the null of non-cointegration is now rejected. Over the 50 years horizon the estimate of $\beta_{1}$ increases to $1.13 .{ }^{11}$ Thus, allowing for a break in the time series and for technological change, we find strong evidence that GS was a predictor of changes in future consumption in the USA.

The results for Germany ${ }^{12}$ in Tables 5 and 6 also investigate discontinuities in the time series, although in this case the effects are associated with World War Two. Without a wartime shift dummy variable, the results in Table 5 all reveal estimates of $\beta_{1}>0$ and in the cases of GSTFP over 30 and 50 years horizons the hypothesis $\beta_{1}=1$ is not rejected, implying that the present value of changes in future consumption over $t=1 \ldots 30$ and $t=1 \ldots .50$ have a one-to-one relationship with the level of GS in period $t_{0}{ }^{13}$ To an extent the German results support those for Britain and the USA, highlighting that, over longer horizons, the augmenting of GS with measures of the value of technological progress yield findings most supportive of using GS as an indicator of

\footnotetext{
${ }^{11}$ The second approach considered estimates the model using FMOLS and applies the Hansen (1992) test for cointegration. The results, not presented here due to space considerations, confirm all the qualitative conclusions on cointegration (and hence robustness) of Table 4 above and re-establish the weak sustainability conclusion, over the 50 year horizon, for the GSTFP variant with the non-rejection of $\beta_{0}=0 \& \beta_{1}=1$ jointly; and $\beta_{1}=1$. Although other methods provide similar results, those reported are based upon the optimal method for the particular circumstance, i.e., when potential endogeneity exists we report IV method results etc. Reporting potentially sub-optimal method results in addition to those regarded as econometrically optimal appears redundant.

${ }^{12}$ Please note that these German results do not coincide exactly with those in Blum et al (2013) due to some differences in estimation and a longer time-span used by Blum et al (2013) starting in 1850.

${ }^{13}$ In this case, utilizing FMOLS and Hansen (1992) does not resolve the issue, as it did with the US. This is likely due to the size of the discontinuity experienced by Germany vis a vis the US: contrasting the effects of World War Two on Germany with those of the Great Depression on the USA.
} 
weak sustainability. ${ }^{14}$ This judgement must be tempered in light of the null of non-cointegration not being rejected for any result reported in Table 5. In contrast, the results in Table 6, which incorporate the war-related shift dummy variable, are more robust, as non-cointegration is rejected in the majority of cases. The chief effect of including the wartime dummy variable is to increase the size of the $\beta_{1}$ estimates. For GS the average of the $\beta_{1}$ estimates for the three time horizons exceeds 2 , pointing to a much faster growth of future consumption than expected. The theory postulates a one to one relationship between GS and the present value of future changes in consumption, but these results show the value of future consumption rose more quickly than would be predicted from the value of GS. The broader GSTFP measure yields lower estimates of $\beta_{1}$ and over the thirty years horizon the hypothesis $\beta_{1}=1$ is not rejected. However, over the 50 year horizon the more robust (given the rejection of non cointegration in this case) estimate of $\beta_{1}$ is 1.88 , which also indicates unexpectedly high future consumption. The puzzle of the German data thus relates to future consumption having grown more quickly than indicated by the theory underlying the use of GS as a sustainable development indicator.

A range of factors may account for this idiosyncratic result, which partly depends on how disinvestment due to war-related destruction and subsequent capital dismantlement are incorporated in the analysis. Further, Germany experienced dramatic institutional changes following World War Two, with possibly profound consequences for its social capital. Changes in social capital may be an important part of investment, but are omitted from conventional GS

\footnotetext{
${ }^{14}$ The results for the three countries embed country specific discount rates, reflecting their real long term interest rates. Our findings are somewhat sensitive to the choice of discount rate. If a common $2.5 \% / y e a r$ discount rate (this is a consumption discount rate adopted present day by the UK Treasury, and also the long term real UK interest rate), then the estimated $\beta_{1}$ in the case of the US gives results, for GS, as B1 $=1.04^{*}, 1.17^{*},-0.03^{+}$and, for GSTFP, B1 $=0.5^{*}$, $0.7^{*^{+}}, 1.25^{*^{+}}$for 20,30 and 50 year horizons respectively. For Germany, also using a 2.5 discount rate for consumption and TFP, gives B1 for GS as $1.16^{*}, 1.38^{*^{+}}$, and 0.32 and for GSTFP B $1=0.621^{*^{+}}, 0.880^{*}, 1.23^{*}$ over 20,30 and 50 year horizons. Where $*$ denotes significantly different from 0 and $^{+}$denotes significantly different from 1. US results using a $2.5 \%$ discount rate are higher than those presented in table 3 whereas the German results using a $2.5 \%$ discount rate are lower than those in table 5 ; in both cases reflecting the lower $(2.5 \%$ v $3.5 \%) /$ higher $(2.5 \% \mathrm{v}$ $1.95 \%$ ) discount rate. Our preference, like that of Ferreira, Hamilton and Vincent (2008) is to use country specific discount rates.
} 
metrics due to measurement problems. Germany's post-war institutional capital was influenced by the continuing presence of Allied forces and wider European integration, for example via the European Coal and Steel Community. In principle, the measure of TFP embedded in GSTFP should reflect changes in social and institutional capital, but the horizon over which the value of intangible capital persists and the appropriate discount rates to use in capturing this effect are uncertain.

Carr (1991) considers post-war institutional changes in Germany, including Marshall Aid and the Federal elections in 1949. The reconstruction of West Germany included democratization and significant amounts of financial assistance, a strong contrast with the Soviet occupation of East Germany where asset-stripping was the norm. Dumke (1990) argues that institutional change and social capabilities were important factors in the German recovery. For De Long and Eichengreen (1991) the resurgent German post-war economy surpassed historical experience, with the Marshall Plan facilitating a pro-growth 'social contract'. Germany, in the post-war period, experienced rapid multi-faceted institutional change, which helped to shape future incomes and consumption, whereas British and American institutions show greater continuity. In contrast to Germany and most West European economies, there are no trend breaks in British and US GDP per capita around World War Two (Greasley et al, 2013b). Within our three country comparison, World War Two is likely to have been a more significant discontinuity for Germany.

The possibility that GS and GSTFP understate the changes in the comprehensive wealth of Germany around the years of World War Two by giving insufficient attention to social and institutional capital provides one explanation of Germany's unexpectedly fast future consumption growth over the 50 year horizon. There are, however, alternative explanations. Blum et al (2013) 
investigate how German territorial adjustments, including those in 1945 may have influenced longer-term consumption trends, but they play down the importance of boundary changes.

An important issue for all tests of genuine savings as an indicator of future consumption is the choice of discount rates. The discount rates used here vary between countries, from $1.95 \% / y e a r$ for Germany to $2.5 \% / y e a r$ for Britain and 3.5\%/year for the USA, reflecting the cross-country variations in long-term real interest rates. Over long periods, these variations in discount rates have substantial effects on the present value of future changes in consumption. Blum et al (2013) conduct sensitivity tests for Germany using a 3\%/year discount rates (which corresponds to the long-run real GDP growth rate) and report an estimate of $\beta_{1}=1.01$ for a 50 years future consumption horizon, and indeed their results, ostensibly, do not reject the strong joint hypothesis $\beta_{0}=0 ; \beta_{1}=1$. However, their findings do not reject non-cointegration and the inclusion of warrelated level shift dummy in the model led to an estimate of $\beta_{1}=1.18$ The conflicting results make it unclear if the finding of unpredictably- fast German consumption growth arises from the choice of discount rate or from the understatement of changes in social and institutional capital.

Finally, we consider the key sustainability hypotheses within the context of panel estimation utilizing data for all three countries simultaneously. In Table 7 the estimates of $\beta_{1}$ conform to the single country estimates, with that for the technology augmented measure GSTFP showing a higher, closer to unity, value over the 50 years horizon. A feature of the no fixed effects panel estimates is that for GSTFP over the 50 year horizon they do not reject the strong joint hypothesis $\beta_{0}=0 ; \beta_{1}=1$. The likely explanation is that the no fixed effects estimates are inefficient, most especially that the estimate of $\beta_{0}$ is broad to accommodate the wide variation in the single country estimates of the intercept parameter. Accordingly the joint null in the fixed effects estimates is less likely to be rejected, which highlights the possible value of including fixed effects in the 
panel regression to represent un-controlled for characteristics of each country which influence the growth of consumption.

This is confirmed statistically by the results presented in Table 8, which include country fixed effects. Column 7 reports tests that reject the redundancy of the fixed effects in 5 of the 6 equations, including for GSTFP over the 50 years horizon. The fixed effects estimates of $\beta_{1}$ reiterate that GS provides a good prediction of future consumption over the shorter 20 and 30 years horizons, where the strong joint null hypothesis is not rejected. The fixed effects estimates of $\beta_{1}$ for GSTFP have similar values to the no fixed effects estimates, and show closer to unity values as the future consumption horizon is extended from 20 to 50 years, although the weaker hypothesis $\beta_{1}=1$ is rejected for all horizons. Finally the robustness of the fixed effects panel estimates is assessed using the Kao test for a cointegrated panel. The results, shown as Table 9, reject the null of no cointegration, confirming the single country analyses of Tables 2-6.

Conclusions to be drawn from the panel data estimates appear clear enough; there are countryspecific characteristics that distinguish the test results for Britain, the USA and Germany. As we have seen, for Germany the distinguishing event is likely to have been World War Two, and for the USA it was the Great Depression. The panel estimates re-affirm the main messages of the individual country results. These are that for these three countries, GS can provide a good indicator of future consumption changes over horizons up to 50 years ahead, and that augmenting GS with a value of technological progress greatly improves the performance of the indicator over longer horizons. 


\section{Concluding Remarks}

In this paper, we conduct tests of Genuine Savings as a long-run indicator of future consumption. We extend previous work using British data to include comparisons with the experiences of Germany and the USA, over a common, 140-year time frame. Especially when estimates of technological progress are included, the main results are that Genuine Savings is a good predictor of trends in future consumption; and that we can often not reject the specific form of the relationship between Genuine Savings and changes in future consumption which is implied by theory. These findings thus strengthen the empirical support for using Genuine Savings as a sustainability indicator, but they also show some distinctive country-specific experiences.

Conventional measures of Genuine Saving, labelled here as GS, adjust produced net investment for natural resource depletion and human capital formation. The GS results for the three countries show remarkable consistency. Over 20 and 30 years horizon, the initial, individual country, estimates of $\beta_{1}$ for GS cluster in range $0.9-1.5$, to broadly support the theoretical consistency of the indicator. Indeed, in four of the six cases the weak sustainability hypothesis $\beta_{1}=1$ is not rejected. What this implies is that the year-on-year change in a country's comprehensive wealth (total capital) is a good indicator of changes in future consumption up to 30 years ahead. However, over 20 and 30 years horizons, in no case is the null of non-cointegration rejected, which diminishes the robustness of the results. Secondly, over the 50 years horizons the initial estimates of $\beta_{1}$ for GS are lower and fall in the range $-0.06-0.39$, to cast some doubt on the utility of the indicator over longer horizons.

Differences emerge when we include a value for technological progress in in our measure of the change in comprehensive wealth, labelled here GSTFP, especially over the longer time horizons. 
In the case of the 50 years horizons the initial estimates of $\beta_{1}$ for GSTFP cluster in the range 1.071.39 , and in two cases the hypothesis $\beta_{1}=1$ is not rejected. However, the hypothesis of noncointegration is only rejected in the British case, highlighting that there are country-specific features of the results. For Britain, we have identified a stable long-run relationship between GSTFP and the present value of future changes in consumption, which corresponds to the earlier results obtained by Greasley et al (2014) over a longer period. This finding does not carry over straightforwardly to the cases of Germany and the USA. The characteristics of the USA and Germany that create the conflicting results are connected to discontinuities in their consumption or investment experiences. For the USA it was the Great Depression which disrupted the stability of economic relationships, for Germany it was World War Two. The robustness of the results for Germany and the USA was further investigated by introducing dummy variables for the years around these discontinuities into the analysis and alternative test for cointegration. In the key case of GSTFP over the 50 years horizons, the null of non-cointegration was then rejected for both countries, pointing to a long-run stable consumption-investment relationships, albeit ones broken by temporary shifts in the levels. For the USA the new estimate of $\beta_{1}$ for GSTFP is 1.13 , which falls within the cluster of the initial estimates, for Germany the new estimate is 1.88 .

The German result incorporating the wartime dummy variables creates an interesting puzzle, since future changes in consumption are noticeably higher than predicted by a one to one relation with GSTFP. One possibility is that the measure GSTFP understates the gains in Germany's social capital post- World War Two as the Nazi regime was replaced by new institutions. More generally, the long horizon results for the USA and Germany highlight that major discontinuities are likely over long spans of history, and that these may have implications for using genuine saving measures as indicators of sustainability over very long time frames. The panel-based estimates reinforce the likely existence of country-specific effects, but they also re-affirm the merit of genuine savings as an indicator of sustainability. 
The policy implication of our work is that governments and development banks should view Genuine Savings as a useful macro-level indicator of weak sustainability. Maintaining a country's total capital (its comprehensive wealth) is, by implication, critical to maintaining its potential for rising future living standards up to 50 years ahead. Adjusting national accounting procedures to allow GS to be calculated each year is thus important, as is the adoption of rules and/or incentives which enforce a "no net decline" in total capital each year, by ensuring enough GDP is re-invested to offset declines in natural, produced or human capital.

Finally, we note that our measure of "well-being" is very narrow, since it consists of consumption expenditure alone. Well-being depends on more than just consumption (Ferreira and Moro, 2010). It is obvious that non-market impacts of economic growth (for example, in terms of urban air pollution, or losses of rural amenities) would also have impacts on well-being, as would changes in working hours. Unfortunately, there are no consistent data series available for these three countries over the time period we study which could be used to correct this short-coming. 


\section{References}

Arrow, K.J., Dasgupta P., Goulder L., Mumford K. and Oleson K.., (2012). Sustainability and the Measurement of Wealth. Environment and Development Economics, 17(3): pp. 317-353

Barbier E.B. and Markandya A. (2013). A New Blueprint for a Green Economy. London: Earthscan.

Blum, M., Hanley, N. and McLaughlin, E. (2013). Genuine savings and future well-being in Germany, 1850-2000. Stirling Economics Discussion paper series, 2013-13.

Bohringer C and Jochem, P. (2007). Measuring the immeasurable: a survey of sustainability indices. Ecological Economics, 63, 1-8.

Carr, W. (1991). A History of Germany, 1815-1990, 4th ed. Routledge: London.

Chichilnisky, G., Heal, G., and Beltratti, A. (1995). The green golden rule. Economics Letters 49, 174-179.

De Long, J.B. and Eichengreen, B. (1991). The Marshall Plan: History's most successful structural adjustment program. NBER Working Paper No. 3899.

Dietz S. and Neumayer E. (2007). Weak and strong sustainability in the SEEA: concepts and measurement. Ecological Economics, 61 (4), 617-626.

Dumke, R.H. (1990). Reassessing the Wirtschaftswunder - Reconstruction and Postwar Growth in West-Germany in an International Context. Oxford Bulletin of Economic Statistics, 52, 451-491.

Engle, R. F. and; Granger, C. W. J. (1987). Co-integration and error correction: Representation, estimation and testing. Econometrica 55 (2), 251-276

Ferreira, S., Hamilton, K., and Vincent, J.R. (2008). Comprehensive wealth and future consumption: Accounting for population growth. World Bank Economic Review, 22, 233-248.

Ferreira, S. and Vincent, J.R. (2005). Genuine savings: Leading indicator of sustainable development? Economic development and cultural change, 53, 737-754.

Ferreira S. and Moro, M. (2010). On the use of subjective well-being data for environmental valuation. Environmental and Resource Economics, 46: 249-273.

Greasley, D., Hanley, N., Kunnas, J., McLaughlin, E., Oxley, L. and Warde, P. (2013). 'Comprehensive investment and future well-being in the USA, 1869-2000'. Stirling Economics Discussion Paper 2013-06.

Greasley, D., Hanley, N., Kunnas, J., McLaughlin, E., Oxley, L. and Warde, P. (2014). 'Testing genuine savings as a forward-looking indicator of future well-being in the (very) long run', Journal of Environmental Economics and Management 61, 171-88. 
Greasley, D., Madsen, J. B. and Wohar, M. E. (2013b). Long-run growth empirics and new challenges for unified theory, Applied Economics, 45, 3973-3987.

Greasley, D. and Oxley, L. (1996). Discontinuities in competitivemness: the impact of the First World War on British industry. Economic History Review, 48, 82-100.

Hamilton, K. and J. Hartwick, Investing exhaustible resource rents and the path of consumption. Canadian Journal of Economics, 2005. 38 (2): p. 615-621.

Hamilton, K., and Clemens, M., (1999). Genuine savings rates in developing countries. World Bank Economic Review, 13 , 33-56.

Hansen, B. E. (1992). Tests for parameter instability in regressions with I(1) processes. Journal of Business and Economic Statistics, 10, 321-35.

Johansen, S. (1991). Estimation and Hypothesis Testing of Cointegration Vectors in Gaussian Vector Autoregressive Models. Econometrica, 59, 1551-1580.

Kao, C. (1999). Spurious Regression and Residual-based Tests for Cointegration in Panel Data. Journal of Econometrics, 90, 1-44.

Kunnas J., McLaughlin E., Hanley N., Greasley D., Oxley L. and Warde P. (2014). "How should pollution from fossil fuels be included in long-run measures of National Accounts and Sustainable Development indicators?" Scandinavian Economic History Review, 62(3), 243-265

Lumsdaine, R., and Papell, D. (1997). Multiple trend breaks and the unit root hypothesis. Review of Economics and Statistics, 79, 212-218.

Maddison, A. (2001). The World Economy: A Millennial Perspective. OECD: Paris

McLaughlin, E., Hanley, N., Greasley, D., Kunnas, J., Oxley, L., and Warde, P. (2014). Historical wealth accounts for Britain: progress and puzzles in measuring the sustainability of economic growth. Oxford Review of Economic Policy. 30, 44-69.

Mota R. P. and Domingos T. (2013). Assessment of the theory of comprehensive national accounting with data for Portugal. Ecological Economics, 95, 188-196.

Mota R.P., Domingos T., and Martins V. (2010). Analysis of genuine savings and potential green net national product. Ecological Economics, 69, 1934-1942.

Neumayer, E. (2010). Weak Versus Strong Sustainability: exploring the limits of two paradigms ( $3^{\text {rd }}$ edition). Edward Elgar, Cheltenham.

Olson, M. (1982). The Rise and Decline of Nations: economic growth, stagflation and social rigidities. Yale University Press, Yale.

Pearce, D., Barbier, E, and Markandya, A. (1990). Sustainable Development: economics and development in the Third World. Earthscan. 
Pearce, D., Markandya, A. and Barbier, E. (1989) Blueprint for a Green Economy. London: Earthscan.

Pearce, D.W. and Atkinson, G. (1993). Capital theory and the measurement of sustainable development: an indicator of weak sustainability. Ecological Economics, 8, 103-108

Pemberton, M. and Ulph, D. (2001). Measuring income and measuring sustainability, Scandinavian Journal of Economics, 103, 25-40.

Perron, P. (1989). The great crash, the oil price shock and the unit root hypothesis. Econometrica $57,1361-1401$.

Perron, P. (1997). Further evidence on breaking trend functions in macroeconomic variables. Journal of Econometrics, 80, 355-385.

Pezzey, J.C.V. (2004). One-sided sustainability tests with amenities, and changes in technology, trade and population. Journal of Environmental Economics and Management, 48, 613-631.

Pezzey, J.C.V., Hanley, H. Turner, K. and Tinch, D. (2006). Comparing augmented sustainability measures for Scotland: Is there a mismatch? Ecological Economics, 57, 70-74.

Phillips, P. C. B. and Ouliaris, S. (1988). Asymptotic properties of residual based tests for cointegration. Econometrica, 58, 165-93.

Phillips, P.C.B, and Hansen, B. (1990). Statistical Inference in Instrumental Variables Regression with I(1) Processes. Review of Economic Studies 57, 99-125.

Solow, R. (1986). On the intergenerational allocation of natural resources. Scandinavian Journal of Economics, 88, 141-149.

Tanguy, I. (2013). Sustainability is compatible with decreasing social welfare. Economics Bulletin $33,1116-1125$.

Weitzman, M. (1997). Sustainability and technical progress. Scandinavian Journal of Economics. 99,1-13.

World Bank (2006). Where is the Wealth of Nations? Washington DC: World Bank.

World Bank (2011). The Changing Wealth of Nations. Washington DC: World Bank.

Zivot, E., and Andrews, D., (1992). Further evidence of the great crash, the oil-price shock and the unit-root hypothesis. Journal of Business and Economic Statistics. 10, 251-270. 
Figure 1: GS per capita, Britain, US and Germany, 1860-2000

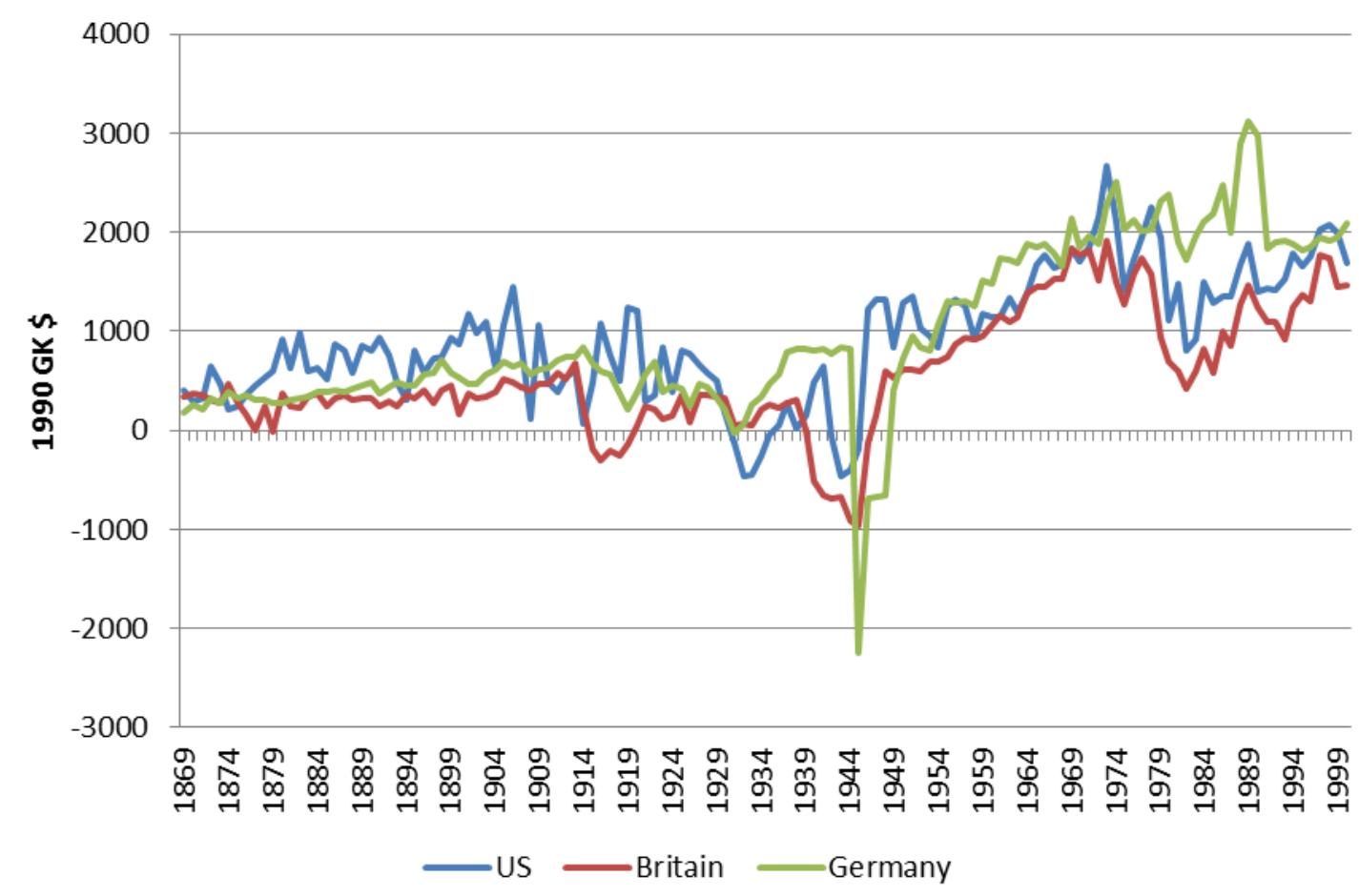

Figure 2: GSTFP per capita, US, Britain and Germany

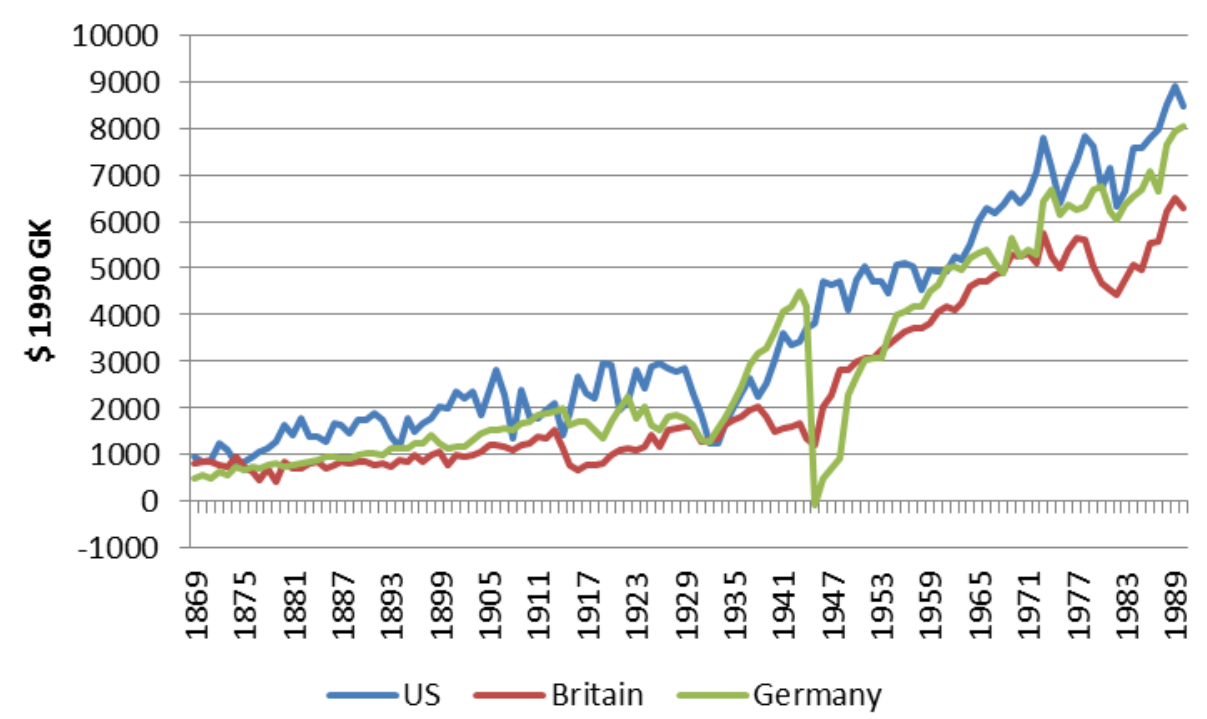

Note: Labour shares in TFP calculations for US, Britain and Germany are 0.6, 0.65, 0.63; discount rates for US, Britain and Germany are: $3.5 \%, 2.5 \%$, and $1.95 \%$. 
Figure 3: Consumption per capita, US, Britain and Germany 1870-2008

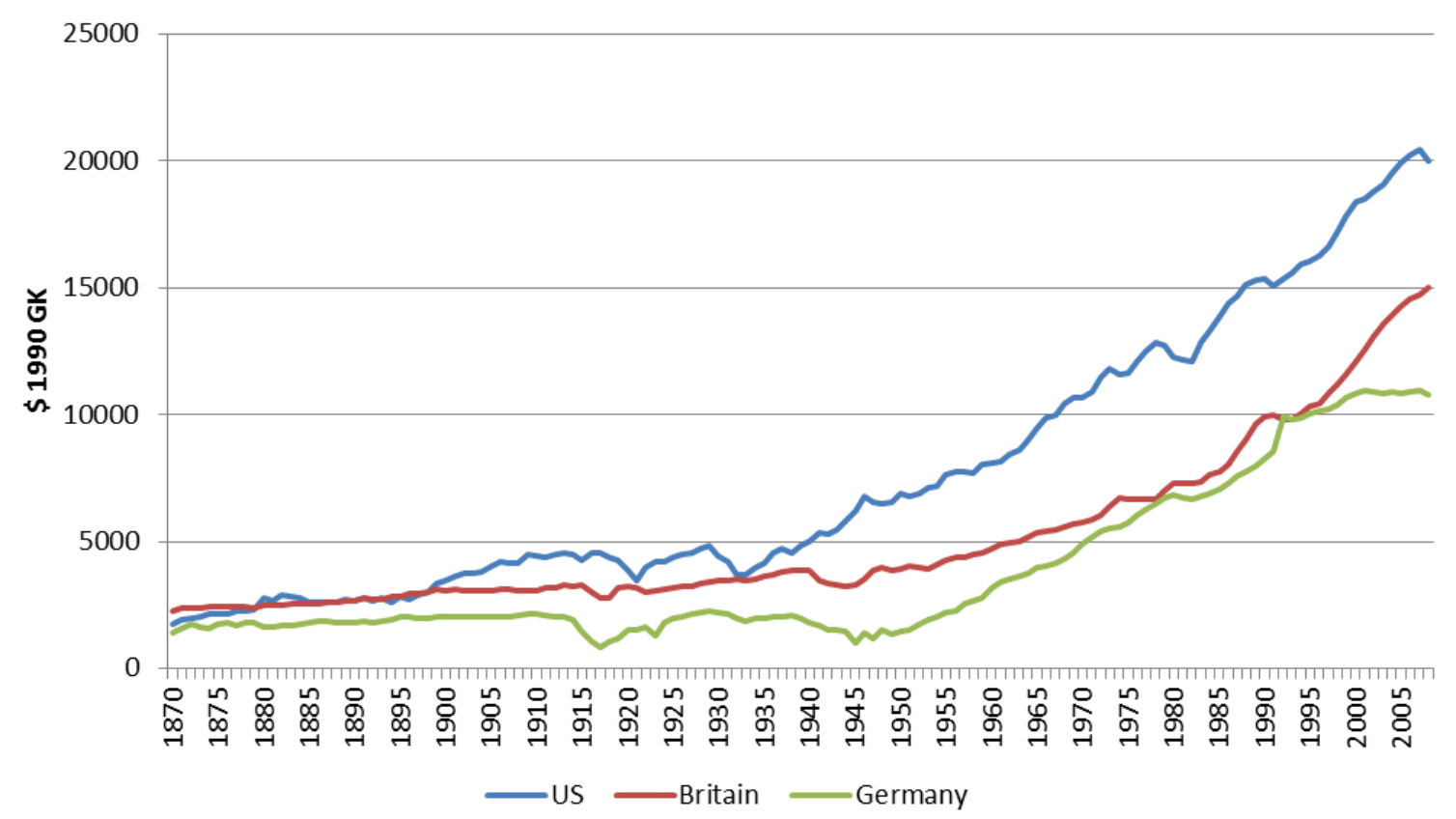

Figure 4: Present value of future changes in US consumption per capita (\$ 1990 GK)

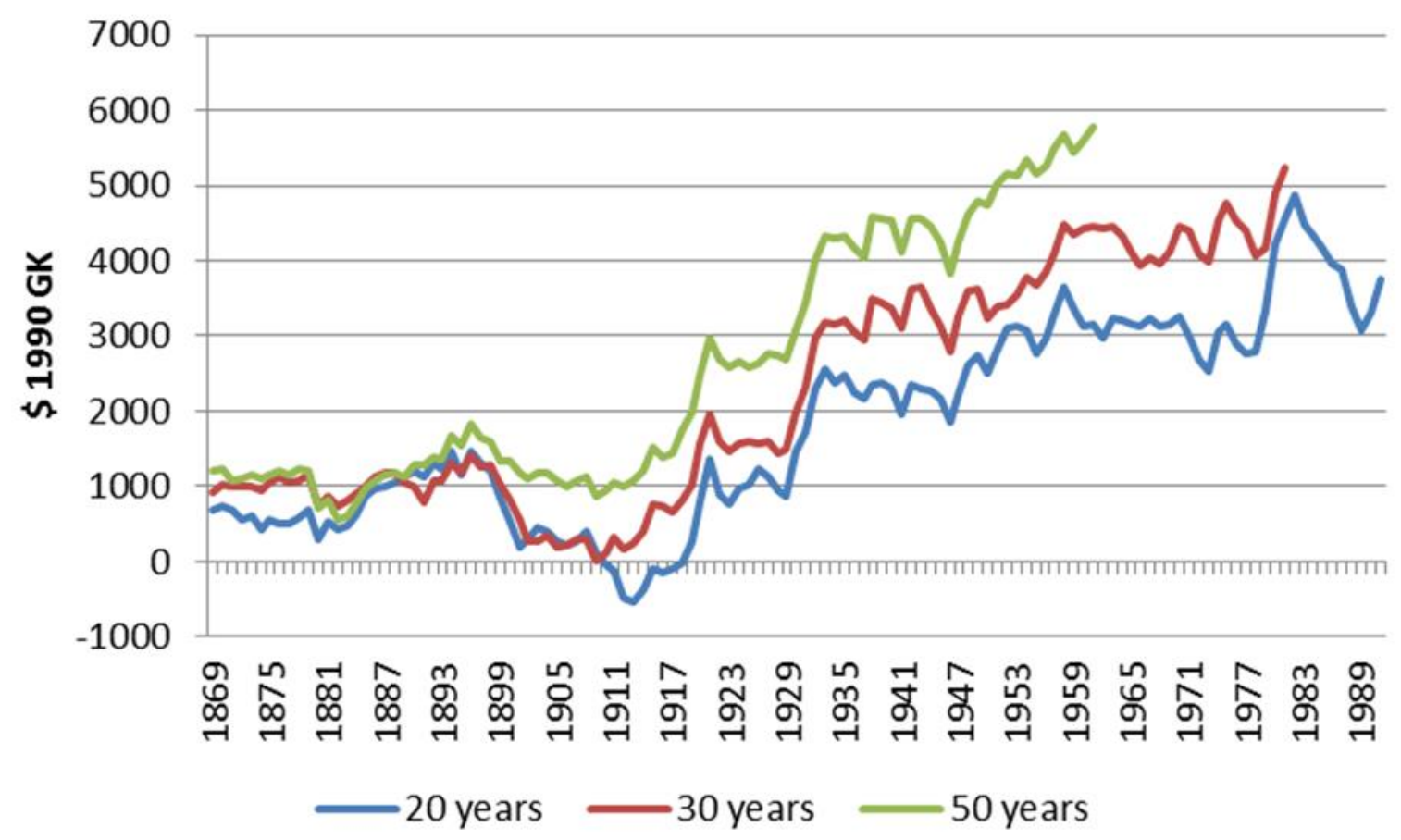


Table 1

Mean Net investment, Green investment and Genuine Savings as a per cent of GDP, 1870-2000

\begin{tabular}{|c|c|c|c|}
\hline & Net investment & Green & GS \\
\hline & $\%$ & $\%$ & $\%$ \\
\hline & \multicolumn{3}{|c|}{$1870-2000$} \\
\hline Britain & 5.40 & 3.53 & 5.71 \\
\hline Germany & 9.99 & 8.78 & 11.59 \\
\hline US & 9.81 & 7.12 & 10.26 \\
\hline Britain & \multicolumn{3}{|c|}{$1946-2000$} \\
\hline Germany & 6.29 & 4.43 & 12.36 \\
\hline US & 9.35 & 8.16 & 8.20 \\
\hline
\end{tabular}


Table 2

E-G OLS Estimates of $\beta_{0}$ and $\beta_{1}$ for Great Britain (2.5\% per annum discount rate)

\begin{tabular}{|c|c|c|c|c|c|c|c|}
\hline 1. & 2. & 3. & 4. & 5. & 6. & 7. & 8. \\
\hline Dependent & Independent & $\beta_{0}$ & $\beta_{1}$ & $\begin{array}{c}\beta_{0}=0 ; \& \\
\beta_{1}=1\end{array}$ & $\beta_{1}=1$ & Sample & $\mathrm{ADF}$ \\
\hline Cons20 & GS & $\begin{array}{c}496.9^{* * *} \\
(0.00)\end{array}$ & $\begin{array}{l}1.22^{* * *} \\
(0.00)\end{array}$ & $\begin{array}{l}47.1^{* * *} \\
(0.00)\end{array}$ & $\begin{array}{c}1.96 \\
(0.16)\end{array}$ & $\begin{array}{c}1870- \\
1990\end{array}$ & -2.64 \\
\hline Cons30 & & $\begin{array}{c}538.6^{* * * *} \\
(0.00)\end{array}$ & $\begin{array}{l}1.55^{* * *} \\
(0.00)\end{array}$ & $\begin{array}{l}95.2^{* * * *} \\
(0.00)\end{array}$ & $\begin{array}{l}13.1^{* * * *} \\
(0.00)\end{array}$ & $\begin{array}{c}1870- \\
1980\end{array}$ & -1.80 \\
\hline Cons50 & & $\begin{array}{c}1159.9^{* *} \\
(0.00)\end{array}$ & $\begin{array}{l}0.389 \\
(0.22)\end{array}$ & $\begin{array}{l}74.9^{* * * *} \\
(0.00)\end{array}$ & $\begin{array}{l}3.51^{* * * *} \\
(0.06)\end{array}$ & $\begin{array}{c}1870- \\
1960\end{array}$ & -0.15 \\
\hline Cons20 & GSTFP & $\begin{array}{c}-333.4^{* * *} \\
(0.00)\end{array}$ & $\begin{array}{c}0.616^{* * *} \\
(0.00) \\
\end{array}$ & $\begin{array}{c}896.9^{* * *} \\
(0.00)\end{array}$ & $\begin{array}{c}210.2^{* * * *} \\
(0.00)\end{array}$ & $\begin{array}{c}1870- \\
1990\end{array}$ & $-3.93 *$ \\
\hline Cons30 & & $\begin{array}{c}-342.8^{* * * *} \\
(0.00)\end{array}$ & $\begin{array}{c}0.777^{* * *} \\
(0.00)\end{array}$ & $\begin{array}{c}609.3^{* * * *} \\
(0.00)\end{array}$ & $\begin{array}{l}98.5^{* * * *} \\
(0.00)\end{array}$ & $\begin{array}{c}1870- \\
1980\end{array}$ & $-3.63 *$ \\
\hline Cons50 & & $\begin{array}{c}-436.2^{* * * *} \\
(0.00)\end{array}$ & $\begin{array}{l}1.17^{* * * *} \\
(0.00)\end{array}$ & $\begin{array}{l}24.8^{* * *} \\
(0.00)\end{array}$ & $\begin{array}{l}10.0^{* * *} \\
(0.00)\end{array}$ & $\begin{array}{c}1870- \\
1960\end{array}$ & $-3.54 *$ \\
\hline
\end{tabular}

Notes: Dependent $=$ the present values of future changes in real wages measured over 20-100 year horizons. For column $3, \mathrm{H}_{0}: \beta_{0}=0 ; \mathrm{H}_{1}: \beta_{0} \neq 0$ and for column $4 \mathrm{H}_{0}: \beta_{1}=0 ; \mathrm{H}_{1}: \beta_{1} \neq 0$ are tested using a t test where $* * *, * *, *$ denotes significantly different from zero at the $1 \%, 5 \%$ and $10 \%$ levels and figures in parentheses are $\mathrm{p}$ values. For column $5 \mathrm{H}_{0}: \beta_{0}=0$ and $\beta_{1}=1 ; \mathrm{H}_{1}: \beta_{0} \neq 0$ and $\beta_{1} \neq 1$ are tested jointly using a Wald test where * denotes significantly different from zero and unity respectively at the $5 \%$ level. For column $6, \mathrm{H}_{0}: \beta_{1}=1 ; \mathrm{H}_{1}: \beta_{1} \neq 1$ is tested using a t test where * denotes significantly different from unity at the 5\% level. For column 8 ADF represents the Augmented Dickey Fuller statistic (corrected for the problem of Generated Regressors) where the degree of augmentation is determined by the Hannan-Quinn Information Criteria. A * represents rejects the null of non-stationarity at the 5\% level and $* *$ at the $10 \%$ level. E-G is Engle-Grainger. 
Table 3

E-G OLS Estimates of $\beta_{0}$ and $\beta_{1}$ for USA ( $3.5 \%$ per annum discount rate)

\begin{tabular}{|c|l|c|l|c|c|c|c|}
\hline 1. & 2. & 3. & 4. & 5. & 6. & 7. & 8. \\
\hline Dependent & Independent & $\beta_{0}$ & $\beta_{1}$ & $\begin{array}{c}\beta_{0}=0 ; \& \\
\beta_{1}=1\end{array}$ & $\beta_{1}=1$ & Sample & ADF \\
& & & & & & \\
\hline Cons20 & GS & $999.1^{* * *}$ & $0.93^{* * *}$ & $73.7^{* * *}$ & 0.15 & $1870-1990$ & - \\
& & $(0.00)$ & $(0.00)$ & $(0.00)$ & $(0.70)$ & & 2.27 \\
\hline Cons30 & & $1412.3^{* *}$ & $1.01^{* * *}$ & $114.2^{* * *}$ & 0.003 & $1870-1980$ & - \\
& & $(0.00)$ & & $(0.00)$ & $(0.95)$ & & 1.68 \\
\hline Cons50 & & $2599.1^{* *}$ & -0.06 & $130.9^{* * *}$ & $7.75^{* * *}$ & $1870-1960$ & 0.36 \\
& & $(0.00)$ & $(0.87)$ & $(0.00)$ & $(0.00)$ & & \\
\hline Cons20 & \multirow{2}{*}{ GSTFP } & 73.4 & $0.48^{* * *}$ & $930.5^{* * *}$ & $278.7^{* * *}$ & $1870-1990$ & - \\
& & $(0.57)$ & $(0.00)$ & $(0.00)$ & $(0.00)$ & & 3.15 \\
\hline Cons30 & & 152.2 & $0.65^{* * *}$ & $227.0^{* * *}$ & $73.3^{* * *}$ & $1870-1980$ & - \\
& & $(0.33)$ & $(0.00)$ & $(0.00)$ & $(0.00)$ & & 2.89 \\
\hline Cons50 & & -107.9 & $1.07^{* * *}$ & 1.04 & 0.67 & $1870-1960$ & - \\
& & $(0.65)$ & $(0.00)$ & $(0.59)$ & $(0.41)$ & & 2.75 \\
\hline
\end{tabular}

See Table 2 footnotes for explanations of null/alternative hypotheses and levels of significance. 
Table 4

E-G OLS Estimates of $\beta_{0}$ and $\beta_{1}$ for USA including a dummy variable

(3.5\% per annum discount rate)

\begin{tabular}{|c|c|c|c|c|c|c|c|}
\hline 1. & 2. & 3. & 4. & 5. & 6. & 7. & 8. \\
\hline Dependent & Independent & $\beta_{0}$ & $\beta_{1}$ & $\begin{array}{c}\beta_{0}=0 ; \& \\
\beta_{1}=1\end{array}$ & $\beta_{1}=1$ & Sample & $\mathrm{ADF}$ \\
\hline Cons 20 & GS & $\begin{array}{l}536.9^{* *} \\
(0.01)\end{array}$ & $\begin{array}{l}1.29^{* * * *} \\
(0.00)\end{array}$ & $\begin{array}{l}60.8^{* * * *} \\
(0.00)\end{array}$ & $\begin{array}{c}2.42 \\
(0.12)\end{array}$ & $\begin{array}{c}1870- \\
1990\end{array}$ & -3.13 \\
\hline Cons 30 & & $\begin{array}{c}792.7^{* * *} \\
(0.00) \\
\end{array}$ & $\begin{array}{l}1.50^{* * * *} \\
(0.00) \\
\end{array}$ & $\begin{array}{c}103.8^{* * *} \\
(0.00)\end{array}$ & $\begin{array}{l}5.24^{* * *} \\
(0.02)\end{array}$ & $\begin{array}{c}1870- \\
1980 \\
\end{array}$ & -2.81 \\
\hline Cons50 & & $\begin{array}{c}1772.5^{* *} \\
(0.00)\end{array}$ & $\begin{array}{l}0.81^{* * * *} \\
(0.00)\end{array}$ & $\begin{array}{l}94.3^{* * *} \\
(0.00)\end{array}$ & $\begin{array}{c}0.21 \\
(0.65)\end{array}$ & $\begin{array}{c}1870- \\
1960\end{array}$ & -1.05 \\
\hline Cons 20 & GSTFP & $\begin{array}{l}-160.4 \\
(0.19)\end{array}$ & $\begin{array}{l}0.52^{* * * *} \\
(0.00)\end{array}$ & $\begin{array}{c}1250.7^{* * *} \\
(0.00)\end{array}$ & $\begin{array}{c}305.1^{* * * *} \\
(0.00)\end{array}$ & $\begin{array}{c}1870- \\
1990\end{array}$ & $-3.45 * *$ \\
\hline Cons30 & & $\begin{array}{l}-169.2 \\
(0.19)\end{array}$ & $\begin{array}{l}0.70^{* * * *} \\
(0.00)\end{array}$ & $\begin{array}{c}391.5^{* * * *} \\
(0.00)\end{array}$ & $\begin{array}{l}82.6^{* * * *} \\
(0.00)\end{array}$ & $\begin{array}{c}1870- \\
1980\end{array}$ & $-3.98 *$ \\
\hline Cons50 & & $\begin{array}{c}-548.6^{* * *} \\
(0.00)\end{array}$ & $\begin{array}{l}1.13^{* * * *} \\
(0.00)\end{array}$ & $\begin{array}{l}13.9^{* * * *} \\
(0.00)\end{array}$ & $\begin{array}{l}6.59^{* * *} \\
(0.01)\end{array}$ & $\begin{array}{c}1870- \\
1960\end{array}$ & $-5.3^{*}$ \\
\hline
\end{tabular}

See Table 2 footnotes for explanations of null/alternative hypotheses and levels of significance. Dummy for Depression takes value 1 for 1931-1940, zero otherwise. 
Table 5

E-G OLS Estimates of $\beta_{0}$ and $\beta_{1}$ for Germany

(1.95\% per annum discount rate)

\begin{tabular}{|c|l|l|l|l|l|l|l|}
\hline 1. & 2. & 3. & 4. & 5. & 6. & 7. & 8. \\
\hline Dependent & Independent & $\beta_{0}$ & $\beta_{1}$ & $\begin{array}{c}\beta_{0}=0 ; \& \\
\beta_{1}=1\end{array}$ & $\beta_{1}=1$ & Sample & ADF \\
& & & & & \\
\hline Cons20 & GS & 101.5 & $1.22^{* * *}$ & $\begin{array}{c}12.09^{* * *} \\
(0.00)\end{array}$ & $\begin{array}{c}3.22^{*} \\
(0.07)\end{array}$ & $1870-1990$ & -2.72 \\
& & $(0.49)$ & $(0.00)$ & & \\
\hline Cons30 & & $374.1^{*}$ & $1.48^{* * *}$ & $32.5^{* * *}$ & $5.73^{* *}$ & $1870-1980$ & -2.20 \\
& & $(0.08)$ & $(0.00)$ & $(0.00)$ & $(0.02)$ & & \\
\hline Cons50 & & $1596.1^{* * *}$ & 0.34 & $34.7^{* * *}$ & $18.4^{* * *}$ & $1870-1960$ & -0.54 \\
& & $(0.00)$ & $(0.49)$ & $(0.00)$ & $(0.00)$ & & \\
\hline Cons20 & GSTFP & $-298.4^{* * *}$ & $0.63^{* * *}$ & $236.9^{* * *}$ & $57.6^{* * *}$ & $1870-1990$ & -2.00 \\
& & $(0.04)$ & $(0.00)$ & $(0.00)$ & $(0.00)$ & & \\
\hline Cons30 & & $-347.9^{*}$ & $0.93^{* * *}$ & $18.00^{* * *}$ & 0.78 & $1870-1980$ & -2.00 \\
& & $(0.09)$ & $(0.00)$ & $(0.00)$ & $(0.38)$ & & \\
\hline Cons50 & & -210.4 & $1.39^{* * *}$ & $5.88^{*}$ & 2.53 & $1870-1960$ & -1.87 \\
& & $(0.60)$ & $(0.00)$ & $(0.06)$ & $(0.11)$ & & \\
\hline
\end{tabular}

See Table 2 footnotes for explanations of null/alternative hypotheses and levels of significance. 
Table 6

E-G OLS Estimates of $\beta_{0}$ and $\beta_{1}$ for Germany including a dummy variable (1.95\% per annum discount rate)

\begin{tabular}{|c|c|c|l|l|l|l|l|}
\hline 1. & 2. & 3. & 4. & 5. & 6. & 7. & 8. \\
\hline Dependent & Independent & $\beta_{0}$ & $\beta_{1}$ & $\beta_{0}=0 ; \&$ & $\beta_{1}=1$ & Sample & ADF \\
& & & & $\beta_{1}=1$ & & & \\
\hline Cons20 & GS & $-372.3^{* * *}$ & $1.58^{* * *}$ & $35.6^{* * *}$ & $30.3^{* * *}$ & $1870-1990$ & $-5.16^{*}$ \\
& & $(0.00)$ & $(0.00)$ & $(0.00)$ & $(0.00)$ & & \\
\hline Cons30 & & $-385.8^{* *}$ & $2.17^{* * *}$ & $76.4^{* * *}$ & $48.4^{* * *}$ & $1870-1980$ & $-5.26^{*}$ \\
& & $(0.03)$ & $(0.00)$ & $(0.00)$ & $(0.00)$ & & \\
\hline Cons50 & & 210.2 & $2.42^{* * *}$ & $36.1^{* * *}$ & $7.78^{* * *}$ & $1870-1960$ & $-3.73^{* *}$ \\
& & $(0.54)$ & $(0.00)$ & $(0.00)$ & $(0.00)$ & & \\
\hline Cons20 & GSTFP & $-529.5^{* * *}$ & $0.69^{* * *}$ & $329.3^{* * *}$ & $51.5^{* * *}$ & $1870-1990$ & -3.01 \\
& & $(0.00)$ & $(0.00)$ & $(0.00)$ & $(0.00)$ & & \\
\hline Cons30 & & $-751.1^{* * *}$ & $1.04^{* * *}$ & $44.8^{* * *}$ & 0.45 & $1870-1980$ & -3.37 \\
& & $(0.00)$ & $(0.00)$ & $(0.00)$ & $(0.50)$ & & \\
\hline Cons50 & & - & $1.88^{* * *}$ & $20.5^{* * *}$ & $20.12^{* * *}$ & $1870-1960$ & $-4.20^{*}$ \\
& & $1190.7^{* * *}$ & $(0.00)$ & $(0.00)$ & $(0.00)$ & & \\
& & $(0.00)$ & & & & & \\
\hline
\end{tabular}

See Table 2 footnotes for explanations of null/alternative hypotheses and levels of significance. War 1944-48=1 zero otherwise 
Table 7: Estimates of $\beta_{0}$ and $\beta_{1}$

Panel OLS Results- No fixed effects

\begin{tabular}{|l|l|l|l|l|l|l|}
\hline 1. & 2. & 3. & 4. & 5. & 6. & 7. \\
\hline Dependent & Independent & $\beta_{0}$ & $\beta_{1}$ & $\begin{array}{c}\beta_{0}=0 ; \& \\
\beta_{1}=1\end{array}$ & $\beta_{1}=1$ & Sample \\
& & & & & \\
\hline Cons20 & GS & $515.7^{* * *}$ & $1.12^{* * *}$ & $175.6^{* * *}$ & $9.23^{* * * *}$ & $1870-1990$ \\
& & $(0.00)$ & $(0.00)$ & $(0.00)$ & $(0.00)$ & \\
\hline Cons30 & & $703.8^{* * * *}$ & $1.38^{* * *}$ & $493.2^{* * *}$ & $12.8^{* * *}$ & $1870-1980$ \\
& & $(0.00)$ & $(0.00)$ & $(0.00)$ & $(0.00)$ & \\
\hline Cons50 & & $1619.4^{* * *}$ & $0.46^{* * *}$ & $31.6^{* * *}$ & $13.6^{* * * *}$ & $1870-1960$ \\
& & $(0.00)$ & $(0.00)$ & $(0.00)$ & $(0.00)$ & \\
\hline Cons20 & GSTFP & $-186.2^{*}$ & $0.57^{* * *}$ & $5453.3^{* * *}$ & $126.3^{* * * *}$ & $1870-1990$ \\
& & $(0.06)$ & $(0.00)$ & $(0.00)$ & $(0.00)$ & \\
\hline Cons30 & & -150.4 & $0.75^{* * *}$ & $115.4^{* * *}$ & $20.4^{* * *}$ & $1870-1980$ \\
& & $(0.24)$ & $(0.00)$ & $(0.00)$ & $(0.00)$ & \\
\hline Cons50 & & -139.4 & $1.12^{* * * *}$ & 3.55 & $3.42^{*}$ & $1870-1960$ \\
& & $(0.41)$ & $(0.00)$ & $(0.17)$ & $(0.06)$ & \\
\hline
\end{tabular}


Table 8: Estimates of $\beta_{0}$ and $\beta_{1}$

Panel OLS Results - Country fixed effects

\begin{tabular}{|c|c|c|c|c|c|c|c|}
\hline 1. & 2. & 3. & 4. & 5. & 6. & 7. & 8. \\
\hline Dependent & Independent & $\beta_{0}$ & $\beta_{1}$ & $\begin{array}{c}\beta_{0}=0 ; \& \\
\beta_{1}=1\end{array}$ & $\beta_{1}=1$ & $\begin{array}{l}\text { Fixed effect } \\
\text { redundancy }{ }^{1}\end{array}$ & Sample \\
\hline Cons 20 & GS & $\begin{array}{c}509.1^{* * *} \\
(0.00)\end{array}$ & $\begin{array}{l}1.13^{* * *} \\
(0.00)\end{array}$ & $\begin{array}{c}3288.0^{* * *} \\
(0.00)\end{array}$ & $\begin{array}{c}2.58 \\
(0.11)\end{array}$ & $\begin{array}{c}19.02^{* * * *} \\
(0.00)\end{array}$ & $\begin{array}{c}1870- \\
1990\end{array}$ \\
\hline Cons30 & & $\begin{array}{l}735.6^{* * * *} \\
(0.00)\end{array}$ & $\begin{array}{l}1.33^{* * *} \\
(0.00)\end{array}$ & $\begin{array}{c}4677.0^{* * * *} \\
(0.00)\end{array}$ & $\begin{array}{l}5.40^{* * *} \\
(0.02)\end{array}$ & $\begin{array}{l}13.70^{* * * *} \\
(0.00)\end{array}$ & $\begin{array}{c}1870- \\
1980\end{array}$ \\
\hline Cons50 & & $\begin{array}{c}1784.0^{* * * *} \\
(0.00)\end{array}$ & $\begin{array}{c}0.09 \\
(0.56) \\
\end{array}$ & $\begin{array}{c}1788.0^{* * * *} \\
(0.00)\end{array}$ & $\begin{array}{l}30.6^{* * *} \\
(0.00)\end{array}$ & $\begin{array}{c}21.49^{* * * *} \\
(0.00)\end{array}$ & $\begin{array}{l}1870- \\
1960\end{array}$ \\
\hline Cons20 & GSTFP & $\begin{array}{c}-192.8^{*} \\
(0.09)\end{array}$ & $\begin{array}{l}0.57^{* * * *} \\
(0.00)\end{array}$ & $\begin{array}{l}448.9^{* * *} \\
(0.00)\end{array}$ & $\begin{array}{c}107.9^{* * *} \\
(0.00)\end{array}$ & $\begin{array}{c}0.73 \\
(0.70)\end{array}$ & $\begin{array}{c}1870- \\
1990\end{array}$ \\
\hline Cons30 & & $\begin{array}{l}-158.2 \\
(0.32)\end{array}$ & $\begin{array}{l}0.75^{* * *} \\
(0.00)\end{array}$ & $\begin{array}{c}226.7^{* * * *} \\
(0.00)\end{array}$ & $\begin{array}{l}14.3^{* * *} \\
(0.00)\end{array}$ & $\begin{array}{c}5.86^{*} \\
(0.06)\end{array}$ & $\begin{array}{c}1870- \\
1980\end{array}$ \\
\hline Cons50 & & $\begin{array}{l}-211.0 \\
(0.13)\end{array}$ & $\begin{array}{l}1.16^{* * * *} \\
(0.00)\end{array}$ & $\begin{array}{c}1130.0^{* * * *} \\
(0.00)\end{array}$ & $\begin{array}{l}4.11^{* * *} \\
(0.04)\end{array}$ & $\begin{array}{l}9.82^{* * * *} \\
(0.00)\end{array}$ & $\begin{array}{l}1870- \\
1960\end{array}$ \\
\hline
\end{tabular}

${ }^{1}$ The null hypothesis is redundancy of the fixed effects. 
Table 9

Kao Residual Panel Cointegration Test

\begin{tabular}{|l|l|l|}
\hline & & ADF \\
\hline Cons50 & GS & $2.54^{* * *}$ \\
& & $(0.00)$ \\
\hline Cons50 & GSTFP & $-1.44^{*}$ \\
& & $(0.07)$ \\
\hline
\end{tabular}

Null hypothesis is no cointegration. 
Data Appendix: please attach here. 